\title{
The Corporate Census: A Preliminary Exploration $\dagger$
}

\author{
Alfred F. Conard*
}

Professor Conard has provided a much needed article in which he critically examines some of the preconceived notions that have distorted legal thinking about corporations. The author examines the asset size distribution of corporations; the number of corporations, partnerships, and proprietorships as a function of asset size; and the distribution of corporations by number of shareholders. His data indicate that while there is no "typical" corporation, the overwhelming majority of corporations are closely held with assets under a million dollars. This result emphasizes the need for careful legislative drafting in corporate, tax and securities legislation to reflect the different characteristics of the variety of corporate enterprises.

\section{I \\ WHY COUNT?}

One of the delights of legal learning is its supposed freedom from arithmetic. Each case must be justly decided on its particular facts. Quantitative data, such as comments on the defendant's wealth or imsurance coverage, are generally regarded as irrelevant or even prejudicial. But quantities are hard to exclude from an intelligent discussion of the norms of corporate behavior. There are vast differences between the potentialities of corporations with a single shareholder and those with a thousand or a million shareholders, and between the capabilities of a corporation with no assets, and of one with $\$ 1$ million or $\$ 1$ billion worth of assets. A sound understanding of the distribution of assets, revenue, employees, and shareholders among corporations is the foundation of a realistic perspective on corporate behavior.

One could perhaps design legal provisions for companies in each bracket of size, without knowing how many there are, but knowing

\section{Copyright (c) 1975, Alfred F. Conard}

$\dagger$ This article was written as a chapter in Corporations in Perspective, to be published in 1976 by Foundation Press. The author acknowledges the invaluable assistances of Anthony $J$. Heckemeyer, now of the Detroit bar, in statistical verification.

* Henry M. Butzell Professor of Law, University of Michigan. A.B. 1932, Grinnell College; LL.B. 1936, University of Pennsylvania; J.S.D. 1942, Columbia; LL.D. 1971, Grinnell College. 
the numbers will help to establish priorities. This need for numerical analysis is accentuated by the bias built up in famous works on "the corporation," works based entirely on observation of the largest enterprises with the most numerous investors. ${ }^{1}$ There is no basic falsity in any of these works, except perhaps in their titles, but their great success and the absence of countervailing works about smaller enterprises have given rise, in Neil Jacoby's phrase, to the "Myth of the Corporate Economy," whose central motif is that giant corporations increasingly dominate and engross American economic life. ${ }^{2}$

Fixation on the giants of the corporate world may be quite proper for macroeconomists; the decisions made in the giant corporations supply, in part, the directional signals of United States production and consumption. But the same fixation can be very misleading when applied to the problems of corporate governance. Professor Eisenberg has shown in a recent article ${ }^{3}$ that analysis of corporations lias been greatly distorted by assuming that all or most corporations are miniature copies of AT\&T and GM.

My purpose in this Article is to carry further the inquiry into the size distribution of business corporations in the United States. I want to answer the complex question: How many corporations are how big? Since definitive statistics are not available over all parts of the spectrum, I must offer some rather tentative hypotheses. These, I suggest, are worth offering partly because they indicate the potential value of more complete data collection, and partly because they supply a gross conception of corporate dimensions which is likely to be closer to the truth than the vague shapes which precondition much current thinking about corporations and their powers.

\section{II}

\section{The Dollar Size of Corporations}

\section{A. The Spectrum of Dollar Size}

The spectrum of corporation size in dollars can be measured in terms of either assets or sales. Particular corporations may fall in quite different ranks according to the scale chosen; for example, the average utility nay have assets four times its revenues while the reverse may be true for meat processors. Nevertheless, the numbers of

1. A. Berle \& G. Means, The Modern Corporation (1932); P. Druczer, Concept of the CORPoration (1946); H. KahN, Future of the CoRporation (1973).

2. N. Jacoby, Corporate Power aNd Social Responsibitity 20-51 (1973). See note 22 infra.

3. Eisenberg, The Legal Roles of Shareholders and Management in Modern Corporate Decisionmaking, 57 CALIF. L. REV. 1 (1969). 
corporations in the respective ranks of either scale are strikingly similar, as shown in table 1.4

Table 1

Distribution of Corporations by Assets and by Receipts (1968)

$\begin{array}{lcc}\begin{array}{l}\text { Size in assets } \\ \text { or receipts }\end{array} & \begin{array}{c}\text { Percent } \\ \text { by assets }\end{array} & \begin{array}{c}\text { Percent } \\ \text { by receipts }\end{array} \\ \begin{array}{l}\text { None* } \\ \$ 1 \text { to }\end{array} & 3 & 0 \\ \begin{array}{l}\$ 49,999 \\ \$ 50,000\end{array} & 38 & 39 \\ \$ 99,999 & 17 & 13 \\ \begin{array}{l}\$ 100,000 \\ \$ 999,999\end{array} & 36 & 38 \\ \begin{array}{l}\$ 1,000,000 \\ \$ 9,999,999\end{array} & 5 & 9 \\ \begin{array}{l}\$ 10,000,000 \\ \$ 99,999,999\end{array} & 1 & 1 \\ \begin{array}{l}\$ 100,000,000 \\ \text { or more }\end{array} & 0.2 & 0.1 \\ \begin{array}{l}\text { Totals } \\ \text { * The presence of corporations with receipts but no assets probably }\end{array} \\ \begin{array}{l}\text { results from tax returns by corporations which had assets at the } \\ \text { beginning of the year, but had fully liquidated at the year's end } \\ \text { when the return was filed. } \\ * * \text { Rounded to nearest whole number. }\end{array}\end{array}$

This table shows that in 1968 the proportion of corporate millionaires, measured by either assets or by revenues, was not much over 10 percent of all corporations, and the proportion surpassing $\$ 100,000,000$ was not over 0.2 percent. The median corporation had slightly under $\$ 100,000 \mathrm{im}$ assets or receipts. These observations are interesting, but unsatisfying; they pique our curiosity at both ends. If more than a third of the corporations are under $\$ 50,000$, how many are under $\$ 10,000$ ? Under $\$ 1,000$ ? If only 0.2 percent are over $\$ 100$ million, how many are over $\$ 1$ billion? Over $\$ 10$ billion?

In order to obtain a further breakdown of corporations in the smaller brackets, a survey was made of domestic and foreign corporation annual reports filed in Michigan for 1970; these contained reports of assets but not of revenues. ${ }^{5}$ For the upper end of the spectrum a count was made of corporations showing over $\$ 1$ billion dol-

4. See I.R.S., Dep't of the Treasury, Statistics of Income 1968: CorporaTION INCOME TAX RETURNS 26, 59. Comparable data for more recent years was not available when this article was prepared. tion:

5. A sample of Michigan franchise tax returns indicated the following distribu- 
lars in assets. ${ }^{8}$ Treating these data as compatible with Internal Revenue Service statistics based on the corporate income tax returns filed for 1970,7 a rough estimate can be made of corporations over the entire spectrum of asset size. The result is presented in table 2.

\begin{tabular}{lc}
\hline $\begin{array}{c}\text { Assets per corporation } \\
\text { (in dollars) }\end{array}$ & Percent of corporations \\
\cline { 2 - 2 } None & 2.9 \\
1 to 99 & 0.7 \\
100 to 999 & 0.7 \\
\hline 1,000 to 9,999 & 16.0 \\
10.000 to 99,999 & 34.1 \\
100,000 to 999,999 & 36.7 \\
\hline $1,000,000$ to $9,999,999$ & 7.3 \\
$10,000,000$ to $99,999,999$ & 1.4 \\
$100,000,000$ or more & less than 0.5 \\
\hline
\end{tabular}

See note 35 infra.

6. The counts for industrials, retailing, transportation, utilities, and life insurance were taken from The Fortune Directory of the 500 Largest Industrial Corporations, 83 FORTUNe 170 (May 1970); the count for banks was taken from PoLK's WorLD BANK DIRECTORY vi (1971); the counts for casualty and liability insurance companies were made from Best's Agoregates \& Averages: PROPERTY-LiABILITY 16-17 (1971).

7. Preliminary data for assets are available for corporations having zero assets and corporations having more than $\$ 100,000$ in assets. I.R.S., DEP'T OF THE TREASURY, SOURCE BOOK-STATISTICS OF INCOME 1970: CoRporate InCOMES. The total number of corporate tax returns filed for 1970 was $1,665,477$. I.R.S., DEP'T OF THE TREASURY, Statistics of InCOME 1970: Business Income Tax Returns 176. These numbers were used in connection with the Michigan data to predict percentage figures for 1970 as shown.

The compatibility of the Michigan sample, supra note 5, with the I.R.S. reports is indicated by the following comparison:

\begin{tabular}{|c|c|c|}
\hline $\begin{array}{l}\text { Assets per corporation } \\
\text { (in dollars) } \\
\end{array}$ & $\begin{array}{l}\text { Percent of } \\
\text { corporations } \\
\text { Michigan }\end{array}$ & $\begin{array}{l}\text { Percent of } \\
\text { corporations } \\
\text { I.R.S.* }\end{array}$ \\
\hline $\begin{array}{l}\text { None } \\
1 \text { to } 99,999 \\
100,000 \text { to } 999,999\end{array}$ & $\begin{array}{r}2.9 \\
51.5 \\
36.7\end{array}$ & $\begin{array}{r}2.9 \\
54.9 \\
35.9\end{array}$ \\
\hline $\begin{array}{l}1,000,000 \text { to } 9,999,999 \\
10,000.000 \text { to } 99,999,999 \\
100,000,000 \text { or more }\end{array}$ & $\begin{array}{c}7.3 \\
1.4 \\
\text { less than } 0.5 \\
\end{array}$ & $\begin{array}{l}5.3 \\
0.9 \\
0.2\end{array}$ \\
\hline
\end{tabular}

*alculated from I.R.S., DEP'T OF THE TREASURY, STATISTICS OF INCOME 1968: CORPORATION INCOME TAX RETURNS 26.

The principal difference between the two distributions is that the I.R.S. sample shows a larger proportion of corporations with less than $\$ 100,000$ in assets, and a smaller proportion with greater assets. Two factors may combine to explain this. First, the sample of Michigan franchise tax returns was neither large enough, nor selected in such a way, that the results could be statistically evaluated and validated. Second, large interstate corporations which were admitted to do business in Michigan were counted as units, although only a small fraction of their business might be done in Michigan. In the I.R.S. sample, the same interstate corporation would be counted as one unit against a much larger nuniber of one-state corporations in the various states. 
Table 2

Estimated Distribution of Corporations by Assets (1970)

\begin{tabular}{|c|c|c|}
\hline $\begin{array}{l}\text { Value of assets } \\
\text { per corporation }\end{array}$ & $\begin{array}{l}\text { Number of corporations } \\
\text { (rounded to two digits) }\end{array}$ & $\begin{array}{c}\text { Percent } \\
\text { (rounded) }\end{array}$ \\
\hline None & 46,000 & 3 \\
\hline$\$ 1$ to $\$ 99$ & 12,000 & 1 \\
\hline$\$ 100$ to $\$ 999$ & 12,000 & 1 \\
\hline$\$ 1,000$ to $\$ 9,999$ & 284,000 & 17 \\
\hline $\begin{array}{l}\$ 10,000 \text { to } \\
\$ 99,999\end{array}$ & 606,000 & 36 \\
\hline $\begin{array}{l}\$ 100,000 \text { to } \\
\$ 999,999\end{array}$ & 599,000 & 36 \\
\hline $\begin{array}{l}\$ 1,000,000 \text { to } \\
\$ 9,999,999\end{array}$ & 87,000 & 5 \\
\hline $\begin{array}{l}\$ 10,000,000 \text { to } \\
\$ 99,999,999\end{array}$ & 16,000 & 1 \\
\hline $\begin{array}{l}\$ 100,000,000 \text { to } \\
\$ 999,999,999\end{array}$ & 2,300 & 0.1 \\
\hline $\begin{array}{l}\$ 1,000,000,000 \text { to } \\
\$ 9,999,999,999\end{array}$ & 290 & 0.02 \\
\hline $\begin{array}{l}\$ 10,000,000,000 \\
\text { or more }\end{array}$ & 14 & 0.001 \\
\hline Total & $\overline{1,665,000^{*}}$ & $\overline{100 * *}$ \\
\hline
\end{tabular}

A simplified graphic presentation of the same data is presented in figure 1. 
Figure 1

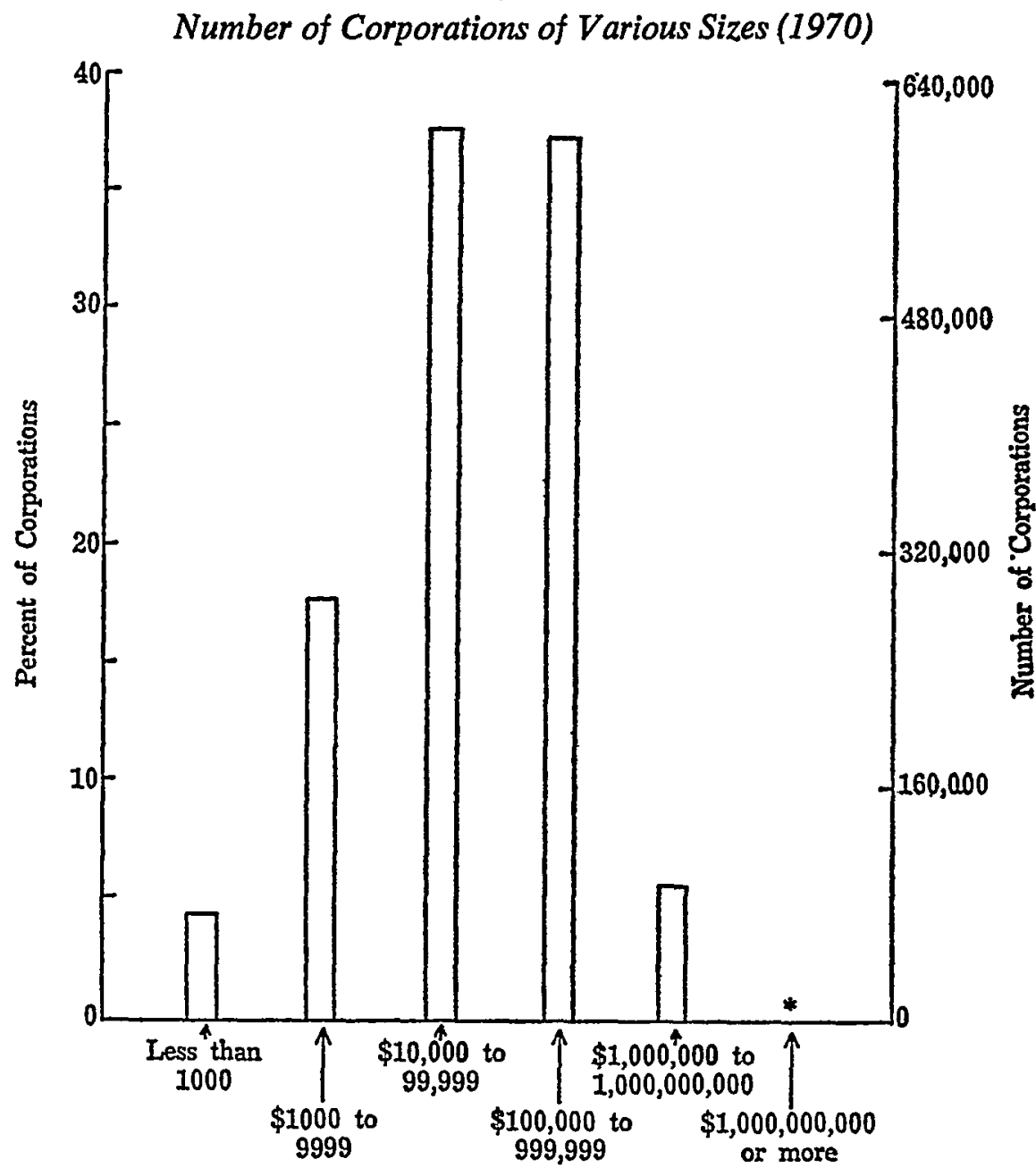

Assets per Corporation in Dollars

* Less than 0.5 percent.

A few simple propositions can be extracted from these presentations. First, the great number of corporations were "small busimess enterprises" having assets worth between $\$ 10,000$ and $\$ 1,000,000$, which could not be listed on a stock exchange, and which would escape the principal regulatory regime of the Securities Exchange Act of $1934 . .^{8}$ The median of assets was about $\$ 100,000$. Second, of the corporations which fell outside the $\$ 10,000$ to $\$ 1,000,000$ bracket, those which were very small outnumbered those which were very large by about three to one.

A convenient four-fold division of corporations by asset size might then be made in these terms:

8. See 15 U.S.C. $\$ \S 78 l(\mathrm{a}),(\mathrm{g})(1)(1970)$. 
1. Small corporations, with assets from zero to $\$ 10,000$, made up more than 20 percent of the total number of corporations.

2. Medium corporations, with assets from $\$ 10,000$ to $\$ 1,000,000$, comprised about 70 percent.

3. Large corporations, with assets from $\$ 1,000,000$ to $\$ 1,000$,000,000 , totaled less than 7 percent.

4. Gigantic corporations, with assets exceeding $\$ 1,000,000,000$, made up less than 0.1 percent.

This distribution may be expected to shift steadily toward the higher dollar brackets as a consequence of inflation and other factors, ${ }^{\circ}$ but the shift should not be massive and will be most marked in the very highest brackets. From 1960 to 1970, the percentage of corporations with assets of $\$ 100$ million or more grew from 0.12 to 0.16 percent (an increase of one-third), but the percentage of corporations with assets of $\$ 1$ million or more grew only from 5.9 to 6.3 percent (an increase of one-fifteenth); therefore, the rough four-fold distribution stated above may still be valid for $1975,{ }^{10}$ and even for later years.

\section{B. Comparative Sizes of Corporations, Partnerships, and Proprietorships}

The idea that corporations are inherently or predominantly big rests partly on a comparison of enterprises im corporate form with enterprises in other forms, of which the most important are partnerships and proprietorships. A graphic comparison of the sizes of enterprises in these forms is presented in figure $2 .{ }^{11}$

9. See N. JaCoBy, CoRporate Power AND Social Responsibility 27-35 (1973) for a comprehensive study of the shift in corporation size.

10. The following figures indicate the direction and amount of movement in corporate asset-size distribution:

Distribution of Corporations Among

Assets per

corporation

Under 100,000

$100,000-999,999$

$1,000,000-9,999,999$

$10,000,000-99,999,999$

$100,000,000$ or more

Totals

* In thousands

BureaU of THE Census, DeP'T OF COMmerce, Statistical Abstract of the United STATES 479 (1973).

Id. at $349,354$.

\begin{tabular}{|c|c|c|c|c|c|}
\hline No.* & Percent) & No.* & $\begin{array}{l}0 \\
\text { ercent) }\end{array}$ & No. 1 & $\begin{array}{l}70 \\
\text { Percent) }\end{array}$ \\
\hline $\begin{array}{r}397.9 \\
190.3 \\
35.6 \\
4.8 \\
0.7\end{array}$ & $\begin{array}{r}(63.2) \\
(30.2) \\
5.7) \\
0.8) \\
(0.11)\end{array}$ & $\begin{array}{r}684.6 \\
389.3 \\
56.3 \\
9.0 \\
1.4\end{array}$ & $\begin{array}{l}(60.0) \\
(34.1) \\
4.9) \\
0.8) \\
(0.12)\end{array}$ & $\begin{array}{r}96 \overline{1.0} \\
599.1 \\
87.0 \\
15.8 \\
2.6\end{array}$ & $\begin{array}{l}(57.7) \\
(36.0) \\
(5.2) \\
0.9) \\
(0.16)\end{array}$ \\
\hline$6 \longdiv { 6 2 9 . 3 }$ & (100) & $1, \overline{40.6}$ & (100) & $1,6 \overline{65.5}$ & (100) \\
\hline
\end{tabular}

11. This comparison is based on receipts rather than assets, because data on receipts were more readily available. 
Figure 2

Number of Proprietorships, Partnerships, and Corporations of Various Sizes (1970)

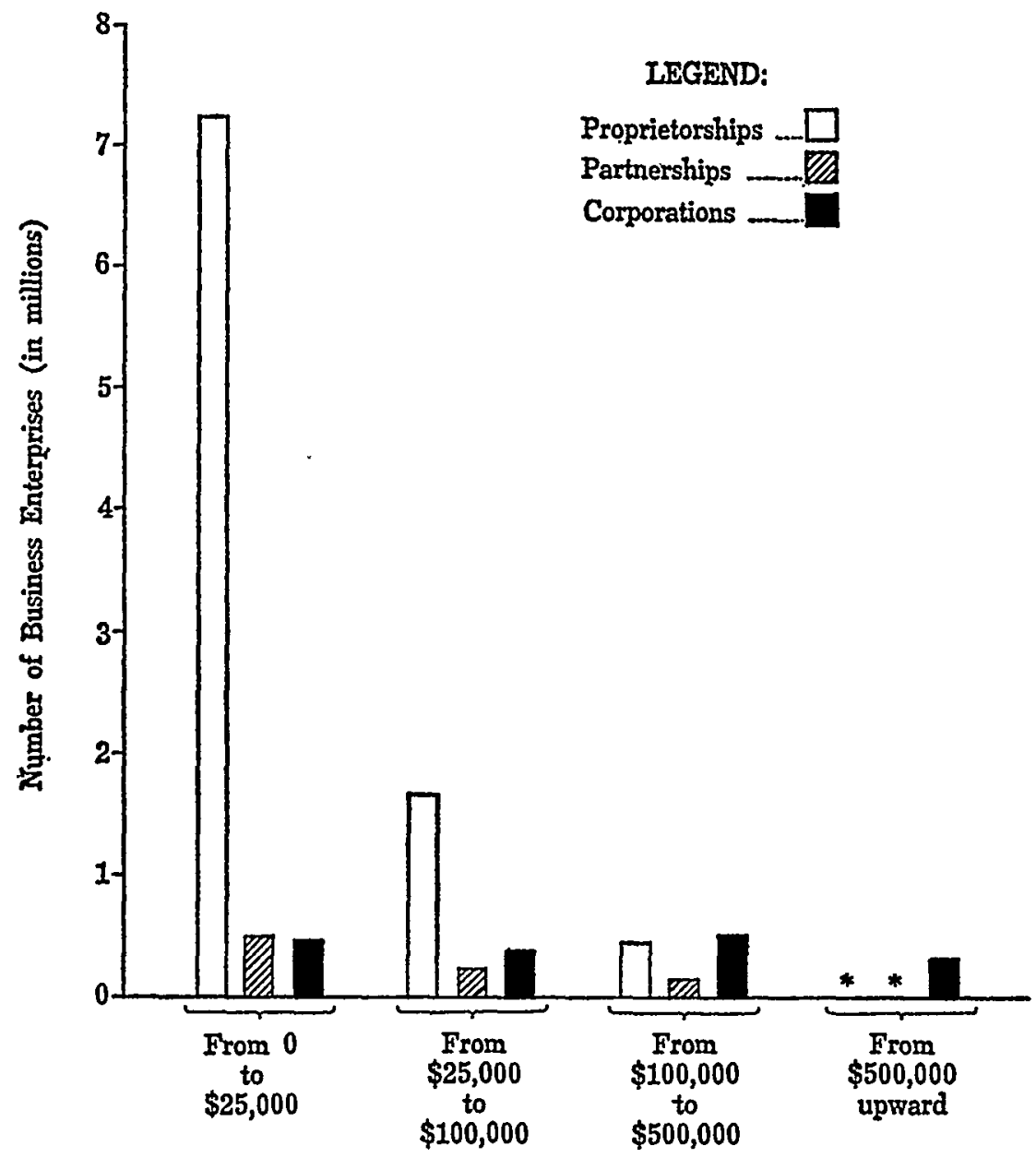

* Less than 50,000 enterprises.

Receipts per Enterprise

Size class

of receipts

\begin{tabular}{lr} 
& Total \\
\hline Total & 12,001 \\
Under $\$ 25,000$ & $(100)$ \\
& 8,200 \\
$\$ 25,000-100,000$ & $(68.3)$ \\
& 2,302 \\
$\$ 100,000-500,000$ & $(19.2)$ \\
& 1,135 \\
$\$ 500,000$ or more & $(9.5)$ \\
& 363 \\
& $(3.0)$
\end{tabular}

Number of enterprises, in thousands (the calculated percentage of the total number of enterprises in parentheses)

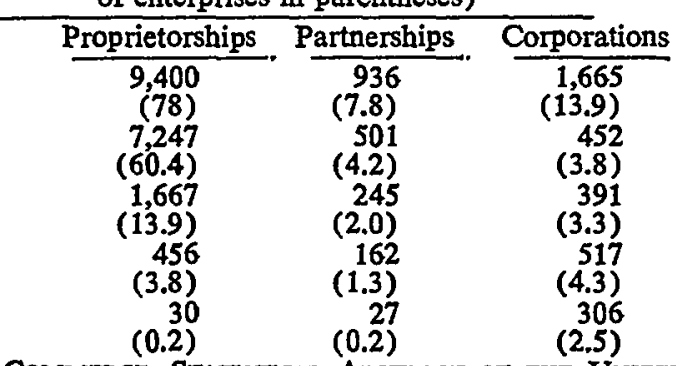

Bureau of the Census, Def't of Commerce, Statistical Abstract of the United Statzs 472 (1973). 
This presentation tends to confirm the association of proprietorships with smallness and of corporations with bigness. One sees at a glance that the smallest bracket of enterprises-those with revenues of less than $\$ 25,000-$ is composed predominantly of proprietorships. At the other extreme, enterprises with revenues exceeding $\$ 500,000$ are almost exclusively corporations.

The fact that most large enterprises are corporations does not imply that corporations are large enterprises. On the contrary, there are more corporations in the I.R.S.'s smallest size bracket (under $\$ 25,000)$, than in the largest ( $\$ 500,000$ or more). The number of small corporations approximates the number of small partnerships. In the medium-large bracket, the number of sole proprietorships nearly equals the number of corporations. Thus, in truth, there is a very great overlap in the sizes of the principal organizational forms. To put the comparison in the simplest terins, corporations are generously distributed throughout the smallest and largest size brackets of enterprise. In the smallest brackets, they are greatly outnumbered by proprietorships, but are counted in the same order of magnitudes as partnerships. In the largest bracket-from $\$ 500,000$ upwardthey are the only numerically significant forin or organization.

\section{The Inequality of Corporations}

The fact that corporations cover an inmensc spectrum of size has the corollary that there are tremendous inequalities among them. Although there are few enterprises comparable to General Motors, there are thousands of others in the billion and million dollar brackets. These large corporations control resources which vastly overshadow those of the numerically dominant smaller organizations. For exanuple, enterprises which receive more than $\$ 500,000$ a year (gross) constitute only 3 percent of busmess enterprises, but enjoy 80 percent of the receipts. ${ }^{12}$ Thus, the numbers of business enter-

12. For percentages of enterprises, see note 11 supra. For percentage of receipts, see the following table.

Size class

of receipts

Total

Under $\$ 25,000$

$\$ 25,000-100,000$

$\$ 100,000-500,000$

$\$ 500,000$ or more

\begin{tabular}{|c|c|c|c|}
\hline & $\begin{array}{l}\text { receipts of enter } \\
\text { (with percentag }\end{array}$ & $\begin{array}{l}\text { rises in each } c \\
\text { in parenthes }\end{array}$ & in billions \\
\hline Total & Proprietorships & Partnerships & Corporations \\
\hline $\begin{array}{l}\overline{2}, \overline{036} \\
(100)\end{array}$ & $\begin{array}{r}238 \\
(11.7)\end{array}$ & $\begin{array}{r}92 \\
(4.5)\end{array}$ & $\begin{array}{l}1,706 \\
(83.8)\end{array}$ \\
\hline 51 & 44 & 4 & $(0.1)^{3}$ \\
\hline $\begin{array}{r}(2.5) \\
117\end{array}$ & $\begin{array}{r}(2.2) \\
82\end{array}$ & $\begin{array}{r}(0.2) \\
13\end{array}$ & $\begin{array}{r}(0.1) \\
22\end{array}$ \\
\hline$(5.7)$ & $(4.0)$ & $(0.6)$ & (1.1) \\
\hline 238 & 83 & 33 & 123 \\
\hline (11.7) & (4.1) & (1.6) & $(6.0)$ \\
\hline & (1.4) & (2.1) & (76.5 \\
\hline
\end{tabular}

Bureau of the Census, Dep't of Commerce, Statistical abstract of the United STATES 472 (1973). 
prises are concentrated in small brackets, but the resources of business enterprises are concentrated among the large brackets. This contrast is illustrated in figure $3 .{ }^{13}$

\section{Figure 3}

Number and Aggregate Receipts of Enterprises of Various Sizes

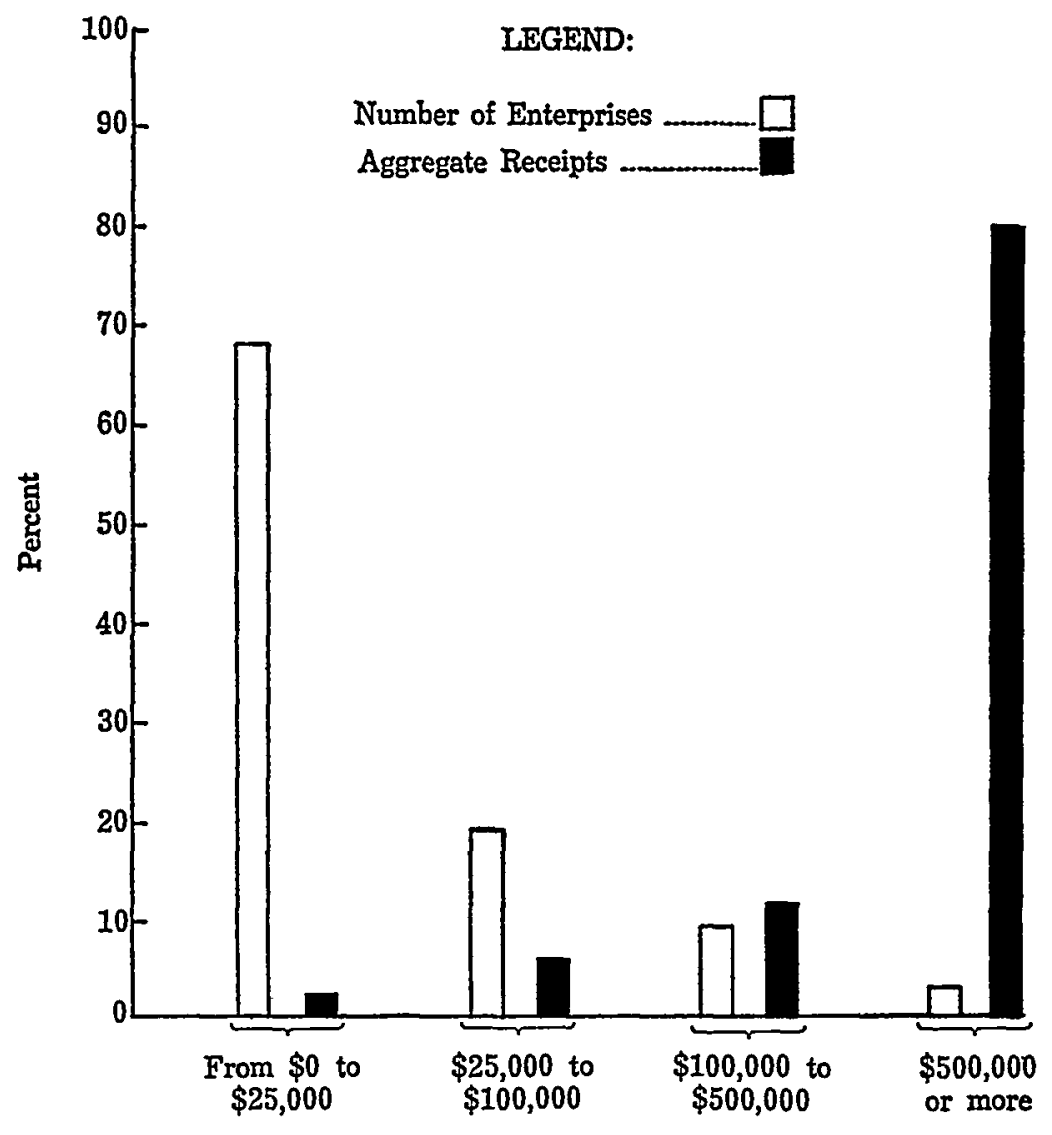

Receipts Per Enterprise

If corporations alone are examined (excluding partnerships and proprietorships), the contrast between numbers and aggregate assets becomes even sharper. The top 20 percent of corporations account for over 90 percent of the receipts, while the bottom half account for less than 2 percent. This relationship is presented in figure $4 .{ }^{14}$

13. Based on data presented in notes 11-12 supra.

14. Based on data presented in notes 11-12 supra. With corporations considered separately, the percentages are as follows: 
Figure 4

Number and Aggregate Receipts of Corporations of Various Sizes

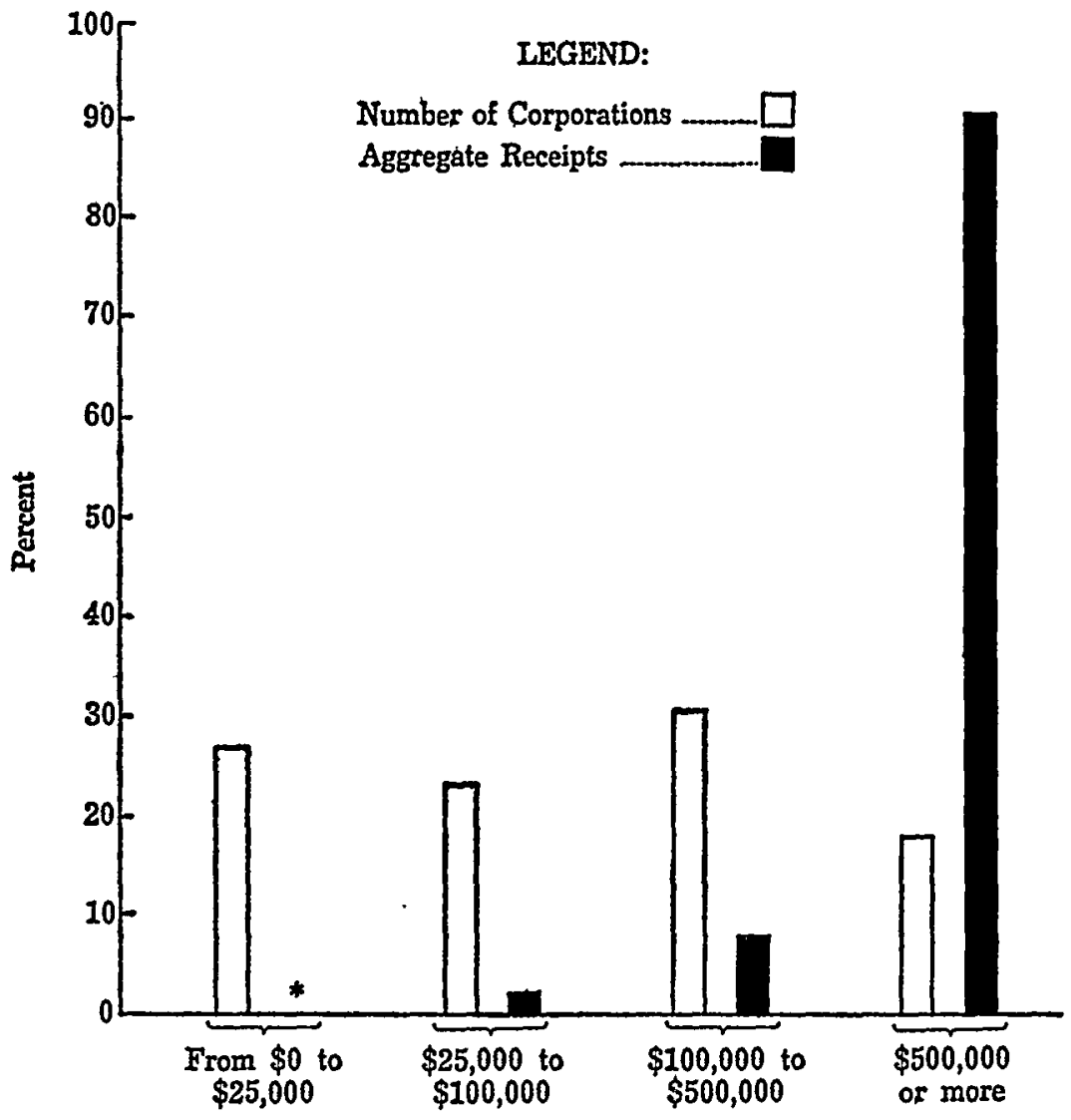

Receipts per Corporation

* Less than 0.5 percent.

Although it is important to recognize the vast gulf between the billionaire corporations and corporations clustered about the national median, ${ }^{15}$ it would be a gross error to think of the billionaire corporations as economic peers of one another. When the giants are separ-

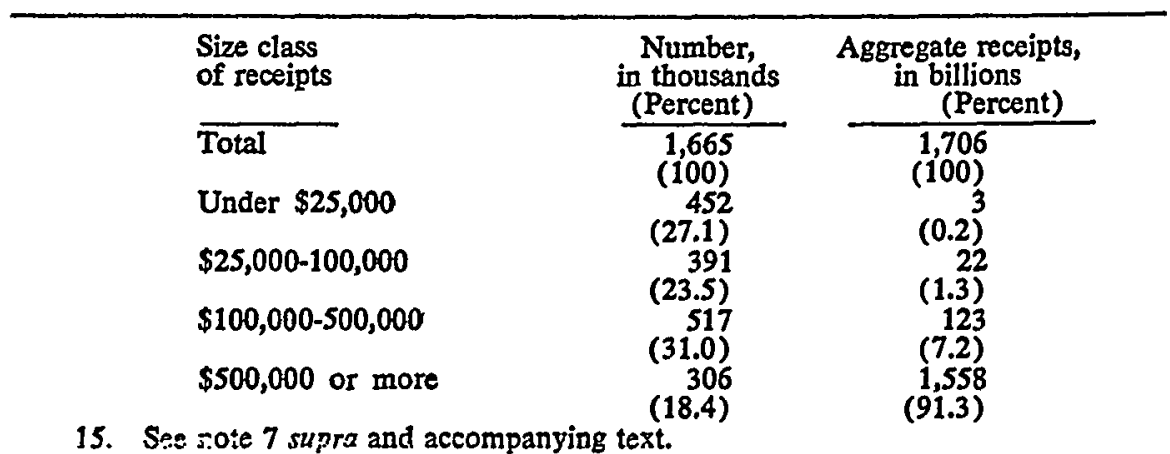

15. Soe sote 7 supra and accompanying text. 
ately analyzed, they are found to repeat the same pattern of dispersion favored in the universe of enterprises-a large nuniber of relatively small giants, and a very small number of super-giants. ${ }^{16}$ This dispersion is illustrated by an examination of the companies included in Fortune's survey of the largest industrial companies for 1970, which distributed themselves as shown in table 3.17 A similar pattern of distribution exists in foreign countries. ${ }^{18}$

\section{Table 3}

\section{Distribution of 1000 Largest Industrial Corporations by Receipts (1970)}

\begin{tabular}{l}
$\begin{array}{l}\text { Sales per company } \\
\text { in billions of dollars }\end{array}$ \\
\hline 0 to 1 \\
1 to 2 \\
2 to 3 \\
3 to 4 \\
4 to 5 \\
5 to 6 \\
6 to 7 \\
7 to 8 \\
8 to 9 \\
9 to 14 \\
14 to 15 \\
15 to 16 \\
16 to 17 \\
17 to 18 \\
18 to 19
\end{tabular}

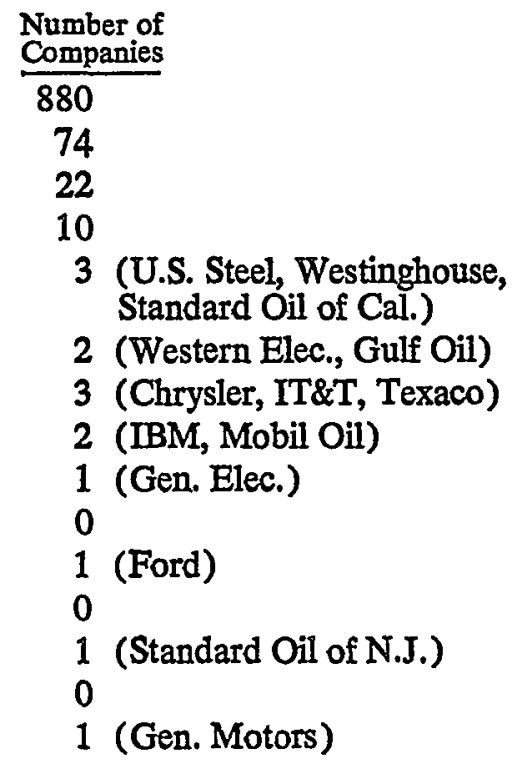

16. The phenomenon of a subset reflecting the distribution pattern of its set has been noticed in other distribution patterns covering dimension spans of this magnitude. G. Zipf, Human Behavior and the Principle of Least EfFort 445-516 (1949).

17. The Fortune Directory of the 500 Largest Industrial Corporations, 83 ForTuNE 170 (May 1970); The Fortune Directory of the Second 500 Largest Industrial Corporations, 83 FORTUNE 100 (June 1971).

18. A tally of the largest industrial enterprises of France ranked by assets reports the following:
Sales in francs
100 million to 1 billion
1 to 10 billion
$\frac{\text { Number of companies }}{332}$
73
3 (Renault, Rhone-Poulenc,
10 billion or more
Prançaise du Pétroles)

Les 500 premières sociétés industrielles françaises, LE CLASSEMEENT 1971 DEs SOcréTÉs FRANÇAISES 25 (LES DOSSIERS D'ENTERPRISE Oct. 1971). The figures do not total 500 partly because I have omitted companies for which sales figures were not given, and companies whose sales were under 100 million francs, with respect to which the list was obviously incomplete.

Likewise, a Swedish survey reports the following distribution of the largest Swedish industrials: 
A problem which troubles many critics is whether the extreme inequality of enterprises is an evil in itself. Some writers depict the immensity of the largest corporations in tones of indignation, as if a corporation 100,000 times as big as the median corporation were a monstrosity. ${ }^{19}$ While this seems unjustified, size does present some serious problems. The most obvious is the domination of markets and the resultant loss of multiparty competition. ${ }^{20}$ But such "dominance" is cominonly regarded as a function of a particular commodity market, and only indirectly related to aggregate size. A conglomerate company may be a billionaire without dominating any particular product market; a specialty manufacturer may dominate a sinall market without even being listed among the nation's 1,000 largest. ${ }^{21}$ However, size may be troublesome in somewhat different ways. The aggregation of so much power in a single set of executives may give them undue political influence, or may expose the national economy to undue shocks from the mistakes made at a single locus of power. ${ }^{22}$

\begin{tabular}{lc}
\hline Sales in Kroner & Number of companies \\
\cline { 2 - 2 } 100 to 1,000 million & 200 \\
1 to 2 billion & 17 \\
2 to 3 billion & 3 \\
3 to 4 billion & 4 \\
4 to 5 billion & 3 (Svenska, Saab, ASEA) \\
5 to 6 billion & 1 (Johnson) \\
6 to 7 billion & 1 (Volvo)
\end{tabular}

Sveriges 500 Största Företag, STOCKHOLM: EKoNOMISK IITTERATUR AB (1972). I have omitted the number of companies with sales of less than 100 million Kroner.

19. This is a normal reaction since our perceptions of the order of the universe are based chiefly on our observations of human beings, domestic animals, homes, schoolhouses, and the like, where a size ratio of $100,000: 1$ would be absurd. If, however, one thinks about the ratio of populations which inhabit Los Angeles and Dixville Notch, or which speak Mandarm Chinese and Ido, or which adhere to Roman Catholic and Shaker religious confessions, one finds these larger proportions. The magnitudes of all these phenomena, like the sizes of corporations, depend on the concurrence and dispersion of human belavior. See generally G. ZIPF, supra note 16. Whether these patterns are the expression of some natural law of human behavior, as Zipf contended, or are merely a mathematical coincidence, they repel the inference that corporate inequalities are inherently abnormal or monstrous.

20. Multiparty competition is regarded by some as the balance wheel of a capitalist economy. See generally J. BLAIR, ECONOMIC CONCENTRATION (1972); W. SHEPHERD, MARRET POWER AND ECONOMIC WeLfare (1970); Hearings on S. 1167 Before the Subcomm. on Antitrust and Monopoly of the Senate Comm. on the Judiciary, 93d Cong., 2d Sess., pt. 3 (1974).

21. Some econounists regard size disparity as a factor impairing competition even without market dominance. See, e.g., Adams, Market Structure and Corporate Power: The Horizontal Dominance Hypothesis Reconsidered, 74 CoLUM. L. REv, 1276 (1974); Edwards, Conglomerate Bigness as a Source of Power, in National Bureau of EcoNOMIC ReSEARCH, Business Concentration AND PRICE POLICY 331 (1955).

22. To the extent that disparities of size are a problem, it becomes important to know whether they are increasing-whether, in more conventional terms, corporate power is increasingly concentrated. An elaborate study of this question has been published by Professor Neil Jacoby. Although he concluded that the increase of concentration is not particularly menacing, his data clearly indicate that concentration is on the increase. See N. JACCBY, CORPORATE POiveR AND SOCIAI RESPONSIBILITY (1973). 
The primary implication of this wide disparity in corporate size is that different laws must be appropriate for corporations of such variety. To have a single code for all seems as fitting as setting up a common set of traffic and safety regulations for B-747's and for tricycles. The social importance of regulation varies over the spectrum of corporate size. With a large fraction of economic transactions conducted by the billionaire corporations, the policies which they pursue in relation to wages, prices, product safety, and environmental protection probably have a dominant influence on the quality of life, while the policies of the smaller companies have a relatively minuscule impact. From this perspective, one can understand the social scientists' equating "the corporation" with multimillion dollar enterprises. Still, it is important for lawyers and lawmakers to recognize that the overwhelming majority of companies are of small to modest size, and that if tax or securities laws and accounting rules erect norms which are impracticable or unnecessary for them, an imjustice is done to a very large number of enterprises and to the people involved in thein.

\section{III}

\section{The Human Dimensions of CoRporations}

Corporations are cominonly measured by their assets, revenues, and profits, rather than by their human constituents. This may be partly because their human assets are so mobile. ${ }^{23}$ But whatever the reason, people are no less important to an industrial corporation than are its raw materials, manufacturing facilities, financing arrangements, or distributing network. ${ }^{24}$ People acting in their three main roles-as employees, as investors, and as customers-are essential to any corporation.

\section{A. Employees}

Although employees are among the most important assets of enterprises, data about them are sparse. ${ }^{25}$ Total numbers of einployees

23. R. Hermanson, Accounting for Human Assets (Occasional Paper No. 14, Bureau of Bus. \& Econ. Resources, School of Bus. Ad., Mich. State Univ. 1964) points out that accountants generally consider admissible assets to be only things owned. Id. at 1.

24. Corporations can be equally important to their employees. In a one-company town - whether it be a West Virginia mining village or a metropolis like Flint, Michigan -there is no other employer who could begin to supply new careers for the personnel of the main corporation. The problem is intensified when workers, for example, coal miners have little experience in other kinds of work, and little knowledge about where to find other jobs. This phenomenon depends on the extent to which a corporation dominates the employinent in a particular locus, rather than merely the abstract size of the company.

25. See R. LIRert, The human Organization: Its Management and Value 146 (1967); E. Flamholtz, The Theory and Measurement of an Individual's Value to 
are commonly published for the largest corporations, but not for the other $1 \frac{2}{3}$ million incorporated enterprises. Figure 5 compares employee numbers with sales volumes and asset amounts for each cohort of 100 companies aniong the nation's 500 largest industrials. ${ }^{28}$

Figure 5

Aggregate Sales, Assets, and Employees of 500 Largest

Industrial Corporations (1970)

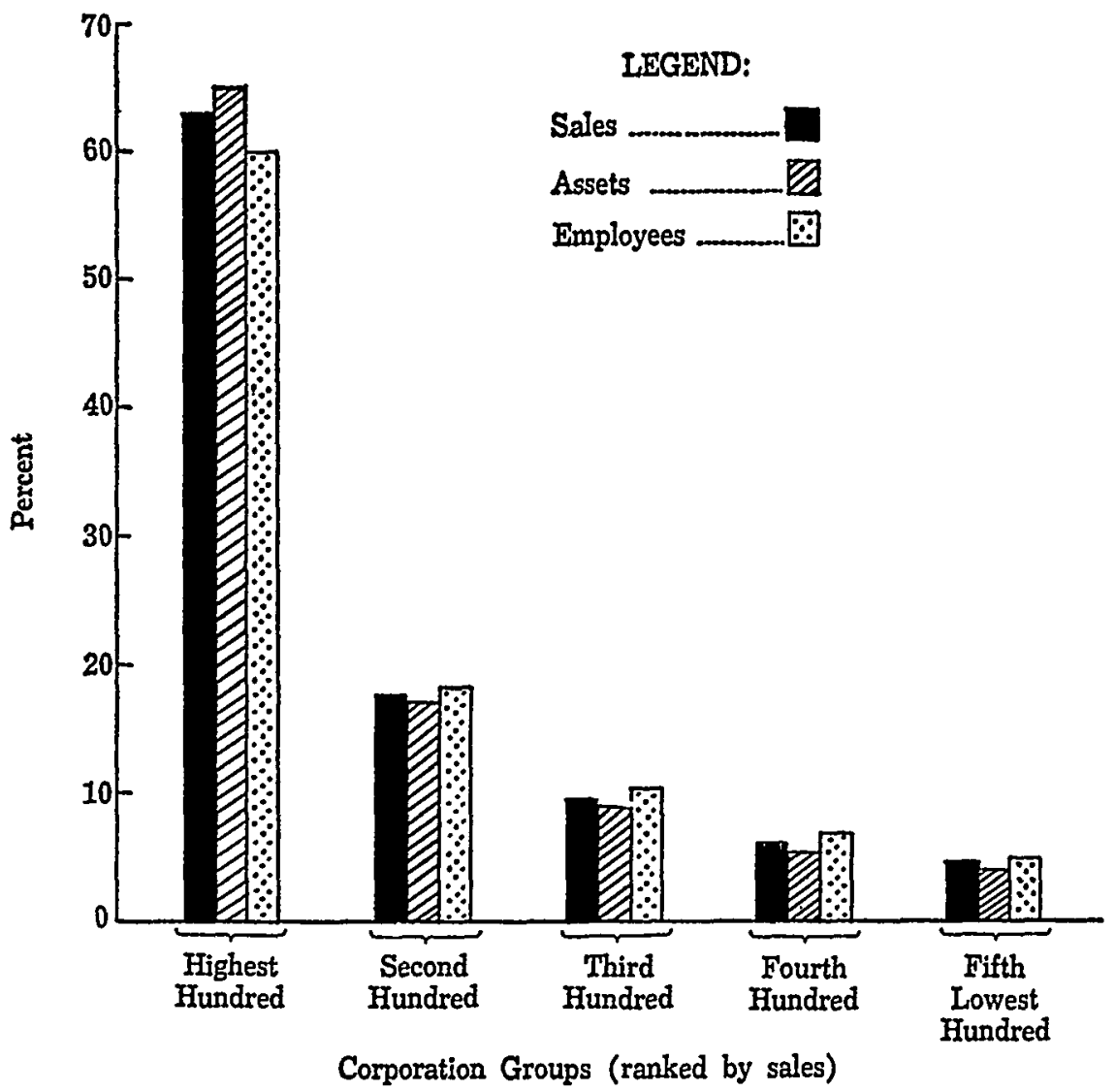

Froin this comparison it is evident that employees are distributed anong companies in approximately the same way as sales and

an Organization, 1969 (unpublished thesis, Univ. Mich.); R. Hermanson, supra note 23; Brummet, Flamholtz \& Pyle, Human Resource Measurement-A Challenge for Accountants, 43 Accounting REv. 217 (1968); Schultz, Investment in Human Capital, 51 AM. ECON. REV. 1 (1961).

26. Percentage of Aggregate Sales, Assets, and Employees of the 500 Largest Corporations (1970):

\begin{tabular}{|c|c|c|c|c|c|}
\hline & $\begin{array}{l}\text { Highest } \\
\text { hundred }\end{array}$ & $\begin{array}{l}\text { Second } \\
\text { hundred }\end{array}$ & $\begin{array}{l}\text { Third } \\
\text { hundred }\end{array}$ & $\underset{\text { hundred }}{\text { Fourth }}$ & $\begin{array}{c}\text { Lowest } \\
\text { hundred }\end{array}$ \\
\hline $\begin{array}{l}\text { Sales } \\
\text { Assets } \\
\text { Employees }\end{array}$ & $\begin{array}{l}62.3 \\
64.5 \\
60.0\end{array}$ & $\begin{array}{l}17.8 \\
17.2 \\
18.2\end{array}$ & $\begin{array}{r}9.4 \\
9.0 \\
10.3\end{array}$ & $\begin{array}{l}6.2 \\
5.4 \\
7.1\end{array}$ & $\begin{array}{l}4.3 \\
3.9 \\
4.8\end{array}$ \\
\hline
\end{tabular}

Bureau of the Census, Dep't of Commerce, Statistical Abstract of the Untred STATES 468, 471 (1971). 
assets. It seems likely that the ratio of employees to assets and sales will rise slightly as we move into the smaller corporation, but it cannot rise very mucl, because sales furnish the money with which ennployees inust be paid. Since approximately 20 percent of the corporations get 90 percent of the receipts, ${ }^{27}$ it is likely that the same 20 percent lave close to 90 percent of the employees. The sinaller 50 percent of corporations which aggregate less than 2 percent of the receipts, probably have approximately 2 percent of the employees.

Taken altogether, corporations receive about 84 percent of all business receipts, ${ }^{28}$ so it is probable that their einployees total 80 percent or more of all business workers. However, these aggregate figures should not obscure the fact that between any two corporations the sales per employee may vary radically. In 1970 the 500 largest industrials averaged sales per employee of approximately $\$ 32,000 .^{29}$ General Motors, engaged in the labor intensive auto industry, averaged sales per employee of only $\$ 27,000$, whereas the comparable figure for Standard Oil of New Jersey was $\$ 116,000$. Comparative figures for a sample of the top 500 industrials are presented in table $4 .{ }^{30}$

Table 4

Sales per Employee of Largest Industrial Corporations

(by rank in sales)

\begin{tabular}{|c|c|c|c|c|}
\hline $\begin{array}{l}\text { Rank in } \\
\text { sales }\end{array}$ & Name & $\begin{array}{l}\text { Employees } \\
\text { (rounded to } \\
\text { three digits) }\end{array}$ & $\begin{array}{c}\text { Sales } \\
\text { (in millions) }\end{array}$ & $\begin{array}{l}\text { Sales per } \\
\text { employee }\end{array}$ \\
\hline 1 & General Motors & 696,000 & $\$ 18,752$ & $\$ 27,000$ \\
\hline 2 & Standard Oil of N.J. & 143,000 & 16,554 & 116,000 \\
\hline 3 & Ford Motor & 432,000 & 14,980 & 35,000 \\
\hline 4 & General Electric & 397,000 & 8,727 & 22,000 \\
\hline 5 & IBM & 269,000 & 7,504 & 28,000 \\
\hline 6 & Mobil Oil & 76,000 & 7,261 & 96,000 \\
\hline 7 & Chrysler & 228,000 & 7,000 & 31,000 \\
\hline 8 & IT\&T & 392,000 & 6,364 & 16,000 \\
\hline 9 & Texaco & 74,000 & 6,350 & 86,000 \\
\hline 10 & Western Electric & 215,000 & 5,856 & 27,000 \\
\hline 20 & General Telephone & 172,000 & 3,439 & 20,000 \\
\hline 100 & Whirlpool & 28,000 & 1,197 & 43,000 \\
\hline 200 & Essex International & 20,000 & 589 & 29,000 \\
\hline 500 & Arvin Industries & 7,850 & 166 & 21,000 \\
\hline
\end{tabular}

27. See text accompanying note 14 supra.

28. See note 12 supra.

29. This figure was derived from the following data: The volume of sales for the first 500 industrials was $\$ 463,929,000,000$. BUREAU of the Census, Dep'T OF CoMMERCE, Statistical Abstract of the United States 468 (1971). These same companies had employees numbering 14,608,000. Id. at 471.

30. See The Fortune Directory of the 500 Largest Industrial Corporations, 83 FORTUNE 170 (May 1970). 


\section{B. Investors}

Corporations are dependent at their birth and at recurrent crises of their lives on those who provide them with the monetary resources they need to sustain themselves. These providers consist principally of shareholders, bondholders, banks, and merchandise creditors. Since banks and creditors generally take very short-term risks from which they can quickly extricate themselves, the more important groups from an organizational perspective are the shareholders and bondholders. These are the persons who are usually characterized as "investors" because they make long-term commitments of assets to their corporations.

There is little public inforination on these investors in assembled data on corporations. ${ }^{31}$ Information on bondholders is almost impossible to obtain. Shareholder information is somewhat more available. The New York Stock Exchange publishes an annual survey of stockholders, ${ }^{32}$ which contains data on the total body of shareholders, but contains no data about how they are distributed among corporations. $^{83}$ Shareholder counts of the largest corporations can, however, be extracted from standard financial manuals. The numbers of shareholders for a few selected industrials are as follows: ${ }^{34}$

31. See Eisenberg, The Legal Role of Shareholders and Management in Modern Corporate Decisionmaking, 57 CAlIF. L. Rev. 1, 40-44 (1969).

32. New York Stock Exchange, Shareownership-1970: Census of ShareOWNERS (1970). The census reputedly went behind broker and banker nominees to find beneficial owners. The corporations covered were said to include 9,900 with more than a million dollars in assets, and more than 300 in shareliolders. Id. at 25.

33. The Statistical Abstract has no such table on sliareholders. The Fortune survey, which compiles data on sales, assets, employees, profits, and growth for each leading corporation, finds no need to tabulate the number of shareholders. The French survey, supra note 18 , is equally silent about sliareliolders. The Swedisl survey referred to in note 18 supra seems to be unique in regarding shareholdersh:p as a dimension of industrial companies worth noting. That survey discloses the following distribution of shareloldership among the Swedish corporate giants:

Numbers of Shareholders in Largest Swedish Corporations

\begin{tabular}{lcc}
$\begin{array}{l}\text { Number of } \\
\text { shareliolders }\end{array}$ & $\begin{array}{c}\text { Swedish Corporations } \\
\text { Number of } \\
\text { corporations } \\
\text { surveyed }\end{array}$ & $\begin{array}{c}\text { Percent of } \\
\text { corporations } \\
\text { surveyed }\end{array}$ \\
\cline { 2 - 3 } 100,001 or more & 3 & 1 \\
$10,001-100,000$ & 43 & 7 \\
$1,001-10,000$ & 64 & 10 \\
$101-1,000$ & 33 & 5 \\
$11-100$ & 74 & 12 \\
$2-10$ & 169 & 27 \\
1 & 249 & 39 \\
\hline Total & 635 & 100
\end{tabular}

* Less than 0.5 percent.

Sveriges 500 Största Företag, StockHolm: EkoNomsK LITTERATUR AB (1972).

34. The rank in sales data in table 5 is based on The Fortune Directory of the 500 Largest Industrial Corporations, 83 FORTUNE 170 (May 1970); The Fortune Directory 
Table 5

Numbers of Shareholders in Largest Industrial Corporations

(by rank in sales)

\begin{tabular}{|c|c|c|}
\hline $\begin{array}{c}\text { Rank in } \\
\text { sales }\end{array}$ & Name & $\begin{array}{l}\text { Shareholders } \\
\text { (rounded to first three digits) }\end{array}$ \\
\hline 1 & General Motors & $1,360,000$ \\
\hline 2 & Standard Oil of N.J. & 808,000 \\
\hline 3 & Ford Motor & 374,000 \\
\hline 4 & General Electric & 521,000 \\
\hline 5 & $\mathrm{IBM}$ & 587,000 \\
\hline 6 & Mobil Oil & 223,000 \\
\hline 7 & Chrysler & 204,000 \\
\hline 8 & IT\&T & 240,000 \\
\hline 9 & Texaco & 283,000 \\
\hline 10 & Western Electric & 1 \\
\hline 20 & General Telephone & 549,000 \\
\hline 100 & Whirlpool & 11,500 \\
\hline 200 & Essex International & 10,600 \\
\hline 500 & Arvin Industries & 9,080 \\
\hline, 000 & Altamil & 4,130 \\
\hline
\end{tabular}

A rough estimate of the distribution of shareholdership over the entire spectrum of corporations appears in table 6.35

of the Second 500 Largest Industrial Corporations, 83 FORTUNE 100 (June 1971). Shareholder data was derived from Moody's INDUSTRIAL MANUAL (1971) and MOODY's Public Utility Manual (1971).

35. Data were drawn from various sources. Shareholder lists were obtained from financial manuals regarding the companies in The Fortune Directory of the 500 Largest Industrial Corporations, 83 Fortune 170 (May 1971); The 50 Largest Commercial Banking Companies, id. at 192; The 50 Largest Life-Insurance Companies, id. at 194; The 50 Largest Retailing Companies, id. at 196; The 50 Largest Transportation Companies, $i d$. at 198 . These lists appeared to include all companies in their categories with shareholders of 10,000 or more. Bnt The 50 Largest Utilities, id. at 200 , obviously did not include all utitities with over 10,000 shareholders, so a count was made from MoOdY's PUBLIC Utilities MaNual (1971). The figures arrived at for the various categories were:

Industrials
Commercial banks
Life insurance
Retailing
Transportation
Utilities
Totals

\begin{tabular}{c}
$10,000-99,999$ \\
shareholders \\
\hline 296 \\
29 \\
3 \\
29 \\
23 \\
123 \\
\hline 503
\end{tabular}

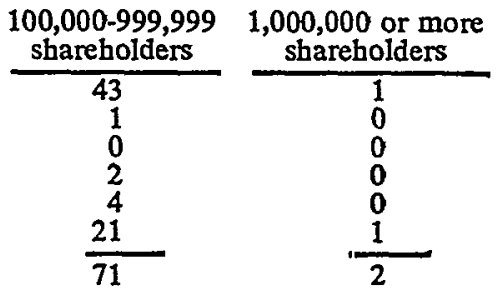

Numbers of companies with less than 10,000 shareholders could not be derived from these lists because they were obviously incomplete for those categories. There may be some overestimation in numbers of shareholders since the numbers of holders of common and preferred shares were added together without discounting for those who held both preferred and common shares. In a systematic sample of 28 industrial, retailing, financial, transportation, and utility companies listed in The Fortune Directory, supra, 
Table 6

Estimated Distribution of Corporations by Numbers of Shareholders (1970)

\begin{tabular}{l}
$\begin{array}{l}\text { Number of } \\
\text { shareholders }\end{array}$ \\
\hline Total \\
1 to 10 \\
11 to 100 \\
101 to 1,000 \\
1,001 to 10,000 \\
10,001 to 100,000 \\
100,001 to $1,000,000$ \\
$1,000,001$ or more
\end{tabular}

Number of corporations $\overline{1,733,000}$ $1,645,000$ 71,000 13,800 2,600 500 70

Percent of corporations 100 94.9

4.1

0.8

0.15

0.03

0.004 0.0001

15 companies presented separate numbers of preferred and common shareholders. MoOdY's Financial MaNual (1971). The percentage of total preferred shareholders to total shareholders-common and preferred-was 16 percent. The overlap in practice is presumed to be much smaller than this percentage.

In order to get shareholder counts for smaller corporations, a survey was made of companies making franchise tax returns in Michgan. In the Michigan survey 276 corporations which had filed franchise tax returns were sent questionnaires and 158 returned responses which indicated shareholder numbers as follows:

\begin{tabular}{rr} 
Shareholders & Percent \\
\hline $11-10$ & 93.5 \\
$11-100$ & 4.0 \\
$101-1,000$ & 0 \\
$1,001-10,000$ & 1.4 \\
10,001 or more & 1.1 \\
& 100.0
\end{tabular}

The responses were weighted in proportion to the number of corporations shown to exist in each size bracket to compensate for the lower rate of response from smaller companies. See note 5 supra. The indications of numbers of companies with more than 100 shareholders are disregarded because of the small representation in the sample, and because of the probable overrepresentation of interstate companies. See note 7 supra. Thus, this data provides a proportion which is probably significant for corporations with 100 or fewer shareholders.

For companies with 100 to 10,000 shareholders, proportions were estimated by interpolation. The interpolation was based on the logarithms of percentages calculated from the data provided by the national sources of shareholder distribution, supra; the total number of corporations, infra; and the percentages revealed by the Michigan survey.

The total number of corporations used in the above calculation was adjusted to in. clude consolidated subsidiaries. The number of corporate income tax returns filed in 1970 was 1,665,477. I.R.S. DEP'T OF THE TREASURY, STATISTICS OF INCOME 1970: BUSINESS INCOME TAX RETURNS 176. This figure excludes consolidated subsidiaries, for which separate tax returns were not filed. See I.R.S., DEP'T OF THE TREasURY, STATISTICS OF INCOME 1968: CORPORATION INCOME TAX RETURNS 173. The Michigan data on corporations with small numbers of shareholders includes subsidiaries. Therefore, the I.R.S. total was corrected by adding the estimated number of consolidated subsidiaries before applying the Michigan percentages. The number of consolidatcd subsidiaries for 1970 was estimated at 67,700 by calculating the ratio of 1968 subsidiaries to the total number of corporations and adjusting for the increased number of corporations by 1970. I.R.S., DeP'T OF THE TREASURY, Statistics OF INCOME 1968: CoRPORATE INCOME TAX RETURNS 124 (62,673 consolidated subsidiaries); id. at 26 (1,541,670 corpo. ration income tax filings). 
Since these estimates are derived from imperfect sources, they should be treated as general indications of magnitude, rather than of precise quantities. Even after allowing for a considerable margin of error, they would justify observations of the following sort:

1. Over 90 percent of corporations have 10 or less shareholders.

2. Less than 1 percent have inore than 100 shareholders.

3. Less than 0.5 percent have inore than 1,000 shareholders.

4. Less than 1,000 corporations have inore than 10,000 shareholders.

5. Less than 100 have inore than 100,000 shareholders.

6. Only two have more than a million shareholders.

A graphic presentation of the distribution is presented in figure 6 . These estimates are compatible with the small amount of information available elsewhere on corporate shareholdership. ${ }^{36}$

Figure 6

Estimated Distribution of Corporations by Numbers of Shareholders

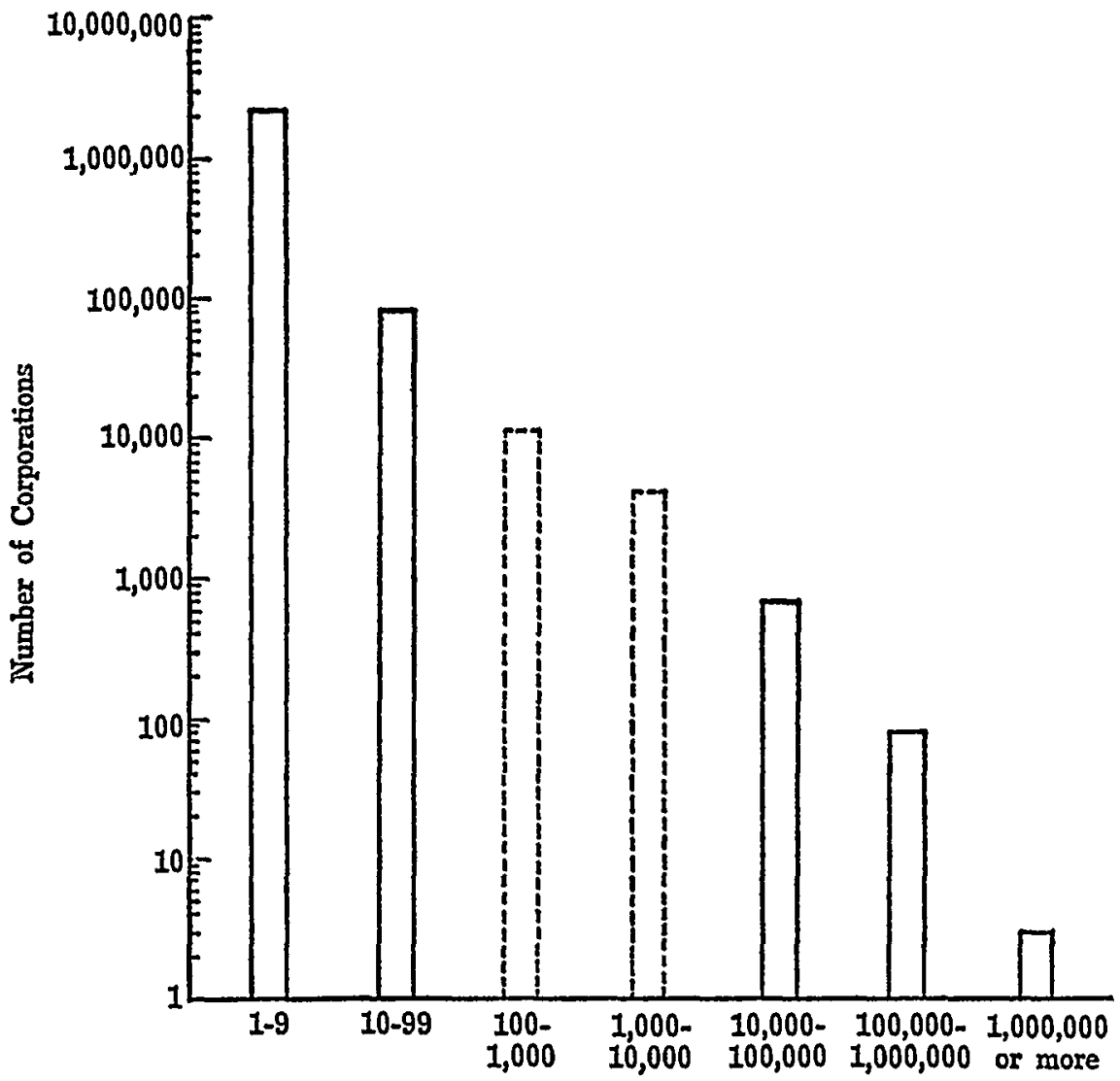

Number of Shareholders per Corporation

36. One such datum is the fact that 7,057 corporations filed reports with the SEC 
These speculations on shareholdership leave aside entirely the important sector of mutuals, cooperatives, savings banks, loan associations, and insurance companies, which have no shareholders. Although some of these enterprises have extremely large asset holdings, their number is relatively small. The total number of savings banks, savings and loan associations, and life insurance companies in 1970 was about 8,000 , of which about 7,000 were probably mutuals. ${ }^{87}$ However, if all their policyholders and depositors were regarded as shareholders, it would significantly increase the number of companies held by nore than $1,000,000$ or more than 100,000 owners.

In conclusion, it should be reiterated that these data represent an estimate of the actual numbers. They are, however, good order of magnitude approximations and should prove provocative enough to stimulate statistic gathering and analysis in this area.

\section{Vendors and Customers}

A complete statement of the human diniensions of any corporation should contain facts about the nunber of people who deal with it, and include the enuployees of enterprises with which it does busi-

in fiscal 1970 under sections 12(b), 12(g), and 15(d) of the Securities Exchange Act of 1934. 15 U.S.C. $\$ 78 l(\mathrm{~b}), l(\mathrm{~g}), o(\mathrm{~d})$ (1970). Registrations under section 12(b) are based on baving a security (bond or stock) listed on a stock exchange; there wero 2,980 of these. Registrations under $12(\mathrm{~g})$ are based on having assets of $\$ 1,000,000$ and registered shareholders of 500; there were 3,963 of these. Registrations under section 15(d) are based on having previously registered securities under the Securities Act, and having 300 shareholders of record; there were 2,414 of these. The discrepancy between the suin of registrations under the various categories $(9,357)$ and the number of reports filed $(7,057)$ is ascribed by an SEC source to overlapping categories and shifts from one category to another during the fiscal year. The explanation seems inadequate, but the writer has no factual basis for advancing other hypotheses. SEC, 36 ANN. REP. 4243 (1970). Nevertheless, the 7,057 total is compatible with the approximately 17,000 corporations estimated to have more than 100 shareholders.

Another datum is the approximately 220,000 tax returns filed under Subchapter S of the Internal Revenue Code. I.R.S., DEP'T OF THE TREASURY, Statistics of INCOMB 1968: CORPORATION INCOME TAX RETURNS 186 . These can be filed only by corporations with 10 or less shareholders. INT. REv. CODE of 1954, § 1371(a). This figure contrasts with but does not contradict the estimated 1.6 million corporations having 10 shareholders or less; however, it is not surprising that a very sunall proportion of the eligible corporations use Subchapter $\mathrm{S}$, in view of the difficulties and inconveniences indicated by most commentators. H. O'NeAL, CLOSE CORPORATIONS $\$ 2.04 \mathrm{a}-\mathrm{g}$ (1971); W. Painter, Corporate and TAX Aspects of Closely Held Corporations 24-39 (1971).

37. The totals for these types of enterprises were:

$$
\begin{array}{lr}
\text { Mutual savings banks } & 494 \\
\text { Savings and loan associations } & 5,669 \\
\text { Life insurance companies } & \mathbf{1 , 8 0 1} \\
\hline & \mathbf{7 , 9 6 4}
\end{array}
$$

Bureau of the Census, Dep't of Commerce, Statistical Abstract of the UntTed STATES 448, 459, 449 (1972). 
ness. The suppliers of General Motors and the suppliers' employees are almost as sure to be affected by GM's fortunes as are GM's own workers. Perhaps more dependent are the dealers and their staffs who sell GM cars to ultimate consumers, and who furnish repair services. Finally, ultimate consumers are affected by the efficiency and continuity of the firm's operations. Every operation of the corporation generates consequences for soine of these many people.

Unfortunately, quantification of corporate relations with these outsiders has hardly begun. One can surmise that the number of persons affected will be roughly proportionate to the volume of the enterprise's activities, but the intensity of effects will vary with the situation of the subjects, just as near neighbors are affected by a blast furnace differently from those who live one or 10 or 100 miles away. Thus, we can only say that large corporations' successes and failures have perceptible effects on persons who are more numerous than the employees and shareholders combimed. Shippers on Penn Central and distributors of GM cars will feel the shock of suspended services along with the company imsiders. Even a distant individual may suffer acutely from the consequences of a rather small corporate mistake in installing a front wheel bearing, or in sterilizing fish in the process of canning.

\section{The Cohabitants}

Beyond those whose means of livelihood are indirectly supplied by corporations, and those who are supplied by the corporation's products, are still others whose health is affected by the corporation's pollution of air and water, whose wealth is affected by the corporation's net contribution to or deduction from commumity finances, and whose happiness is affected by their perception of the corporation as a fairy godmother or a devilish ogre. These groups embrace nearly everyone who inhabits the same country as a corporation; they may be designated the "cohabitants." Their attitudes are just as important to the corporation as the corporation's behavior is to them, because these attitudes affect their votes on political issues and on leaders who in turn influence the corporation.

There is a great deal that could be usefully known about how much corporations are recognized and how favorably they are perceived by their cohabitants. "Institutional advertising" is apparently destined for this broad public, yet very little is known about cohabitants' perceptions of the corporations, either before or after advertising. This lacuna may be a blessing to public relations counselors, but is surely an impediment to legal scholars and social scientists. 


\section{CONCLUSTON}

The primary purpose of this Article is to undermine misconceptions of corporate dimensions which seem to be widely held. The typical corporation is not a multibillion-dollar, multimillion-shareholder enterprise. The median corporation may be one with assets of approximately $\$ 100,000$ and have three shareholders, but there is not, in a meaningful sense, any "typical" corporation. Corporations are spread out along an unbroken spectrum from no assets to billions of dollars worth and from one shareholder to millions. The greatest number of corporations have assets valued between $\$ 10,000$ and $\$ 1,000,000$ and have shareholders numbering less than 10 . But the greatest concentration of assets and revenues are found in a few hundred billionaire corporations.

These observations are offered in the belief that one can understand corporation laws and how they work only by keeping in mind the great variety of corporations to which they may be applied. Many laws, if not most, are appropriate to some types of corporation, but ill-fitting to others. If the laws governing corporations are to be improved, draftsmen must thoughtfully consider the application of each provision to corporations of widely different dimensions and characteristics. This observation apphes not only to the statutes known as "corporation acts," but also to securities laws, securities transfer laws, antitrust laws, tax laws, and accounting rules. 